\title{
Poly(ADP-Ribose) Polymerase Inhibition Down-Regulates Expression of Metastasis-Related Genes in CT26 Colon Carcinoma Cells
}

\author{
Ming Li ${ }^{\mathrm{a}} \quad$ Michael D. Threadgill ${ }^{\mathrm{b}}$ Yalan Wang ${ }^{\mathrm{a}}$ Li Cai $^{\mathrm{a}} \quad \mathrm{Xiao}_{\mathrm{Lin}}{ }^{\mathrm{a}}$ \\ a Department of Pathology, Chongqing Medical University, Chongqing, People's Republic of China; \\ ${ }^{\mathrm{b}}$ Department of Pharmacy and Pharmacology, University of Bath, Bath, UK
}

\section{Key Words}

Cell adhesion - Colorectal cancer - Metastasis - Nuclear

factor- $\mathrm{B} \cdot \mathrm{PARP}$ inhibitors $\cdot$ Poly(ADP-ribose) polymerase

\begin{abstract}
Objectives: The current study was designed to test the hypothesis that inhibition of poly(ADP-ribose) polymerase in colorectal cancer mediates down-regulation of metastasisrelated gene expression through the regulation of nuclear factor- $\kappa \mathrm{B}(\mathrm{NF}-\kappa \mathrm{B})$ activity. Methods: Mouse colon carcinoma cells (CT26) were treated with and without the PARP inhibitor 5-aminoisoquinolin-1(2H)-one hydrochloride (5-AIQ). We investigated adhesion, migration and invasion of differently treated CT26 cells. In addition, the expression levels of PARP, $N F-\kappa B$, integrin $\beta_{1}$, MMP-9 and MMP- 2 as well as the activities of NF- $\kappa$ B, MMP-9 and MMP-2 were determined by Western blot, electrophoretic mobility gel shift assay and zymography, respectively. Results: Inhibition of PARP attenuated the adhesion of CT26 cells to the extracellular matrix and their migration and invasion through Matrigel. In addition, the results of Western blot showed that the expression levels of PARP, NF- $\kappa B$, integrin $\beta_{1}, M M P-9$ and MMP-2 were reduced in 5-AIQ-treated CT26 cells; the activities of NF- $\mathrm{B}, \mathrm{MMP}-9$ and MMP-2 were also suppressed. Conclusions: Inhibition of PARP down-regulates the expression of metastasis-related genes in mouse colon carcinoma cells. This could be, at least in part, through the regulation of NF- $\mathrm{kB}$ activity, but the precise mechanisms of action remain to be elucidated.
\end{abstract}

Copyright $\odot 2009$ S. Karger AG, Basel

\section{Introduction}

Poly(ADP-ribose) polymerase (PARP) is a nuclear enzyme of eukaryotic cells. When activated by DNA singlestrand breaks, PARP uses ADP-ribose units from its substrate $\mathrm{NAD}^{+}$to build a polyanionic poly(ADP-ribose) polymer onto Glu residues on its target proteins, which can include histones and PARP itself (automodification) $[1,2]$. The formation of this polymer then triggers recruitment of the repair apparatus to repair the breaks. Thus PARP controls the repair of DNA damaged by environmental agents and by cancer therapeutic agents such as DNA-targeted cytotoxins (e.g. alkylating agents and topoisomerase II inhibitors) and ionizing radiation (radiotherapy). The role of inhibitors of PARP as potentiators of chemotherapy and radiotherapy has been studied for many years, and several drugs have been evaluated in clinical trials [3-6]. Very recently, pharmacological inhibition of PARP has been proposed as monotherapy in BRCA mutant tumors [7].

In normal cells, excessive DNA damage causes overactivation of PARP, which, in turn, results in rapid depletion of the intracellular NAD ${ }^{+}$and ATP, eventually leading to cellular dysfunction and death [8]. This is particularly evident in ischemia-reperfusion disorders, where inhibition of PARP activity can lead to protection against

This work was supported in part by grants from the National Natural Science Foundation of China (NSFC: 30870946 ) and from the Nature Science Foundation Project of Chongqing (CSTC: 2006BB5288).

\section{KARGER}

Fax +4161306 1234 E-Mail karger@karger.ch www.karger.com

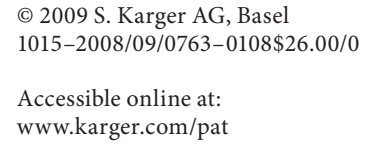


cell death and organ damage in models of hemorrhagic shock, myocardial infarction, and ischemic kidney disease and ischemic liver disease, inter alia [9-13]. More recently, overactivation of PARP has been shown to be involved in the regulation of inflammatory processes, with some inhibitors of PARP showing anti-inflammatory effects in animal models, particularly those of acute inflammation [14-18]. This pro-inflammatory effect of PARP is associated with some transcription factors, particularly nuclear factor (NF)-кB [19-21]. A recent report has shown that PARP inhibitors affect NF- $\kappa \mathrm{B}$ activation and gene expression via the activation of the $\mathrm{PI}_{3}$-kinase/ Akt (protein kinase B) pathway, which can inhibit mitogen-activated protein kinase activation for example [22]. On the other hand, automodification of PARP by poly(ADP-ribosylation) up-regulates the formation of the NF- $\kappa \mathrm{B} \cdot \mathrm{DNA}$ complex and enhances the NF- $\kappa \mathrm{B}-\mathrm{de}-$ pendent expression of the genes for some inflammatory mediators [23].

Inhibitors of PARP have long been proposed as potentiators of DNA-damaging chemotherapy and of radiotherapy through inhibition of repair of damaged DNA, but only a few papers show overexpression of PARP in tumors, e.g. colon cancer [24], human cervical cancer [25] and prostate cancer [26]. PARP has recently been implicated in the processes of angiogenesis, interestingly including control of expression of HIF- $1 \alpha$ and thus vascular endothelial growth factor [27], and some inhibitors of the enzymatic activity of PARP show anti-angiogenic effects [28]. We have previously demonstrated that inhibition of PARP activity with 5-aminoisoquinolin-1 $(2 \mathrm{H})$ one hydrochloride (5-AIQ) suppresses the expression of P-selectin and intercellular adhesion molecule-1 (ICAM1) in vivo in an animal model of lung injury [16] and in vitro in human colon cancer cells [29]. These data suggest that, in addition to chemo- and radiosensitization, inhibitors of PARP may have other roles in the treatment of cancer.

5-AIQ is a highly water-soluble inhibitor of PARP activity [30]. In vitro, it is moderately potent and highly selective for inhibition of PARP activity compared with the inhibition of the mono(ADP-ribosyl)ation activity of diphtheria toxin [30], and is exquisitely potent in vivo in protecting against ischemia-reperfusion-triggered organ damage in a rodent model of hemorrhagic shock [9]. 5AIQ can reduce ischemia/reperfusion injury of the liver [13] and has been shown to provide beneficial effects in rodent models of heart transplantation [31], spinal cord injury [15] and acute lung injury [16]. Notably, 5-AIQ inhibits neutrophil-mediated lung injury through down- regulation of the expression of P-selectin and ICAM-1 [16]. However, the effects of 5-AIQ (and other PARP inhibitors) on the NF- $\mathrm{KB}$-mediated invasive aspects of tumor metastases are unknown. It is known that integrins mediate the adhesion of cancer cells to the extracellular matrix (ECM) [32]; additionally, matrix metalloproteinase-9 (MMP-9) and -2 (MMP-2) play a major role in the degradation of type-IV collagen [33], which is the major component of ECM. All of them play an important role in tumor metastasis. Therefore, in this study, we investigated the role and mechanism(s) by which pharmacological inhibition of PARP with 5-AIQ may lead to the downregulation of NF- $\kappa$ B, integrin $\beta_{1}$, MMP-9 and MMP-2, thereby inhibiting adhesion of mouse colon carcinoma cells (CT26) to ECM and invasion through Matrigel.

\section{Materials and Methods}

\section{Cell Culture}

CT26 cells were a kind gift from Prof. Wei Yuquan (Sichuan University, China); they were cultured in RPMI 1640 (Invitrogen, Gibco, Calif., USA) supplemented with $10 \%$ fetal bovine serum (FBS), penicillin (100 $\mathrm{IU} \mathrm{ml}^{-1}$ ) and $100 \mu \mathrm{g} \mathrm{ml}^{-1}$ streptomycin in a humidified atmosphere of $5 \% \mathrm{CO}_{2}$ and $95 \%$ air at $37^{\circ} \mathrm{C}$. For each experiment, subconfluent cells in culture flasks were used after trypsinization.

\section{Adhesion Assay}

Cell adhesion was assayed as described by Odero-Marah et al. [34]. Briefly, 96-well culture plates were precoated with $50 \mu \mathrm{l}$ of a serially diluted fibronectin $\left(30 \mu \mathrm{g} \mathrm{ml}^{-1}\right.$; Santa Cruz Biotechnology, Santa Cruz, Calif., USA) solution and air-dried overnight at $4^{\circ} \mathrm{C}$. The plates were then blocked with bovine serum albumin $(10$ $\mathrm{mg} \mathrm{ml}^{-1}$ ) in phosphate-buffered saline (PBS) at $37^{\circ} \mathrm{C}$ for $2 \mathrm{~h}$. CT26 cells were pretreated for $16 \mathrm{~h}$ with or without 5-AIQ $(100 \mu \mathrm{M})$ before being resuspended in serum-free medium. Cells $\left(2.5 \times 10^{5}\right.$ $\left.\mathrm{ml}^{-1}\right)$ were seeded to wells coated with fibronectin $\left(200 \mu \mathrm{l} \mathrm{well}{ }^{-1}\right)$ and incubated at $37^{\circ} \mathrm{C}$ for $30 \mathrm{~min}$. Non-adherent cells were removed by gentle washing with PBS. Cells were incubated with 3 (4,5-dimethylthiazol-2-yl)-2,5-diphenyltetrazolium bromide (2.0 $\left.\mathrm{mg} \mathrm{ml}^{-1}, 50 \mu \mathrm{l} \mathrm{well}{ }^{-1}\right)$ at $37^{\circ} \mathrm{C}$ for $4 \mathrm{~h}$; dimethylsulfoxide $(150 \mu \mathrm{l}$ well ${ }^{-1}$ ) was then added and the plates were oscillated for $10 \mathrm{~min}$ to solubilize the formazan crystals. The absorbance of each well was measured in a microplate reader (Labsystems) at $630 \mathrm{~nm}$.

The results are presented as percentage attachment, where $100 \%$ attachment corresponds to the attachment of untreated cells exposed to fibronectin.

Migration and Invasion Assay

Migration and invasive abilities were measured in Transwell cell culture chambers (Costar) according to the method of Wick et al. [35], with a slight modification. In brief, the lower surface of the membrane was coated with fibronectin (Santa Cruz Biotechnology; $5.0 \mu \mathrm{g} \mathrm{well}^{-1}$ ) and then air-dried overnight at room temperature. CT26 cells, pretreated for $16 \mathrm{~h}$ with or without 5-AIQ 
$(100 \mu \mathrm{M})$, were resuspended in serum-free RPMI 1640. Cells at a density of $1 \times 10^{6} \mathrm{ml}^{-1}$ were seeded in each upper chamber with serum-free RPMI 1640 medium $(100 \mu \mathrm{l})$. RPMI 1640 medium with $10 \%$ FBS $(600 \mu \mathrm{l})$ was added to the lower chambers as a chemoattractant. At least three chambers were used for each experimental group. After incubation for $24 \mathrm{~h}$ in a humidified $\mathrm{CO}_{2}$ incubator at $37^{\circ} \mathrm{C}$, the inserts were fixed with methanol and stained with hematoxylin. The cells on the upper surface of the membrane were removed using cotton swabs. The cells on the lower side of membrane were counted by light microscopy in five fields (up, down, left, right and middle) at a magnification of $\times 400$

For the invasion assay, the upper surface of the membrane (6.5-mm diameter and $8-\mu \mathrm{m}$ pore size) was coated with Matrigel (diluted 1:5 with serum-free RPMI 1640 medium; Becton Dickinson, Bedford, Mass., USA) at $30 \mu \mathrm{l} \mathrm{well}{ }^{-1}$. The procedure then followed the migration assay as above.

The results are presented as percentage invasion, where 100\% invasion corresponds to the invasion of untreated cells.

\section{Western Blot Analysis}

CT26 cells were pretreated with or without 5-AIQ $(100 \mu \mathrm{M})$ for $16 \mathrm{~h}$, then washed with ice-cold PBS and lysed with M-PER ${ }^{\circledR}$ Mammalian Protein Extraction Reagent (Pierce), following the manufacturer's instructions. The nuclear proteins were extracted with NE-PER ${ }^{\circledR}$ nuclear and cytoplasmic extraction reagents (Pierce), following the manufacturer's instructions. Western blot analyses were carried out using procedures described by Lee et al. [36]. The protein concentrations from lysates of treated or untreated CT2 6 cells were determined by the Bradford protein assay. Equal amounts of protein $(10-30 \mu \mathrm{g})$ were subjected to electrophoresis in SDS-polyacrylamide gels (8\%) and were transferred to a polyvinylidene fluoride membrane. After blocking nonspecific binding sites, membranes were incubated with appropriate antibodies against PARP-1, NF- $\mathrm{Bp} 65$, integrin $\beta_{1}$, MMP-9, MMP-2 and actin (diluted 1:200-1:500; Santa Cruz Biotechnology) overnight at $4^{\circ} \mathrm{C}$. The immunoreactive bands were detected with horseradish peroxidase-conjugated secondary antibodies and visualized by enhanced chemiluminescence (Santa Cruz Biotechnology).

\section{Electrophoretic Mobility Gel Shift Assay (EMSA)}

CT26 cells were pretreated with or without 5-AIQ $(100 \mu \mathrm{M})$ for $16 \mathrm{~h}$. Nuclear proteins were extracted with NE-PER nuclear and cytoplasmic extraction reagents (Pierce), following the manufacturer's instructions. Equal amounts of nuclear protein extracts were assayed for binding of NF- $\kappa \mathrm{B}$ protein to DNA using the LightShift chemiluminescence EMSA kit (Pierce) with a biotin-end-labeled NF- $\mathrm{B}$ oligonucleotide (5'-AGT-TGA-GGGGAC-TTT-CCC-AGG-C-3'; a gift from Dr. Wang Fengchao, Third Military Medical University of China). Assay mixtures that contained nuclear protein extracts $(3 \mu \mathrm{g})$, reaction buffer [Tris $(10$ $\mathrm{mM}), \mathrm{KCl}(50 \mathrm{mM})$, dithiothreitol (1.0 mM), glycerol (2.5\%), $\mathrm{MgCl}_{2}$ $(5.0 \mathrm{mM})$, Nonidet P-40 (0.05\%), poly (dI-dC) $(1.0 \mu \mathrm{g})]$ and biotinend-labeled NF- $\mathrm{KB}$ oligonucleotides $(2 \mu \mathrm{l})$ were incubated in a final volume of $20 \mu \mathrm{l}$ for $20 \mathrm{~min}$ at room temperature to allow binding of protein to DNA. Specific binding was confirmed by adding unlabeled probe (a gift from Dr. Wang Fengchao; $2 \mu \mathrm{l}$ ) as a specific competitor. Protein-DNA complexes were resolved on non-denaturing $6 \%$ polyacrylamide gels in $0.5 \times \mathrm{TBE}$, transferred to nylon membranes via electroblotting and UV cross- linked. The DNA-protein complexes were visualized with streptavidin-horseradish peroxidase followed by measurement of the chemiluminescence. For the supershift assay, the binding reaction was carried out in the presence of an anti-NF- $\mathrm{\kappa p} 65$ antibody (Santa Cruz Biotechnology).

\section{Zymography}

Equal numbers of CT26 cells were pretreated with or without 5-AIQ $(100 \mu \mathrm{M})$ for $16 \mathrm{~h}$, and gelatinase activities were detected as described by Quesada et al. [37]. The culture medium was collected and centrifuged at $14,000 \mathrm{rpm}$ for $5 \mathrm{~min}$ at $4^{\circ} \mathrm{C}$ to remove cell debris. The supernatant was mixed with $4 \times$ nonreducing sample buffer (4:1 v/v) and electrophoresed on a 10\% SDS-polyacrylamide gel containing gelatin $(0.1 \%$; Sigma) as a substrate for MMP-2 and MMP-9. After electrophoresis, gels were washed in $2.5 \%$ Triton X-100 for $1 \mathrm{~h}$ to remove SDS and then incubated overnight at $37^{\circ} \mathrm{C}$ in developing buffer [Tris $(50 \mathrm{~mm}), \mathrm{HCl}(40 \mathrm{~mm})$, $\mathrm{NaCl}(200 \mathrm{mM}), \mathrm{CaCl}_{2}(5.0 \mathrm{~mm})$ and Briji (0.2\%)]. After incubation, gels were stained with Coomassie brilliant blue $(0.5 \%)$ in methanol (40\%), acetic acid (10\%) and water (50\%) for $30 \mathrm{~min}$ followed by destaining. Gelatinolytic activity manifested as horizontal white bands on a blue background.

\section{Statistical Analysis}

All results were expressed as the mean \pm SD. Student's t test was used to determine the significance $(p<0.05)$ of the differences between the mean values.

\section{Results}

\section{PARP Inhibition Attenuates the Adhesion of CT26 \\ Cells to ECM and Their Migration and Invasion}

To determine whether PARP inhibition affects the integrin-mediated cancer cell adhesion to ECM, CT26 cells were incubated with or without the PARP inhibitor 5AIQ and then their ability to adhere to fibronectin-coated plates was determined. Treatment of CT26 cells with this agent led to a significantly decreased adhesion of the cells to this matrix compared with a control group (fig. 1a).

To examine the role of PARP on the migration and invasion of CT26 cells, we used a Transwell chamber assay to examine the migratory and invasive potentials of CT26 cells pretreated with 5-AIQ in comparison with cells without this pretreatment (fig. 2). In this migration assay, the 5-AIQ-pretreated cells showed a decrease of $30 \%$ in the level of penetration through the microporous membrane compared with penetration of the CT26 cells which had received no drug (fig. 1b). Coincidently, the number of permeating 5-AIQ-pretreated CT26 cells was decreased by $37 \%$ in Matrigel-coated Transwell chambers compared with the number of permeating 5-AIQ-untreated CT26 cells (fig. 1c). All these data showed that 


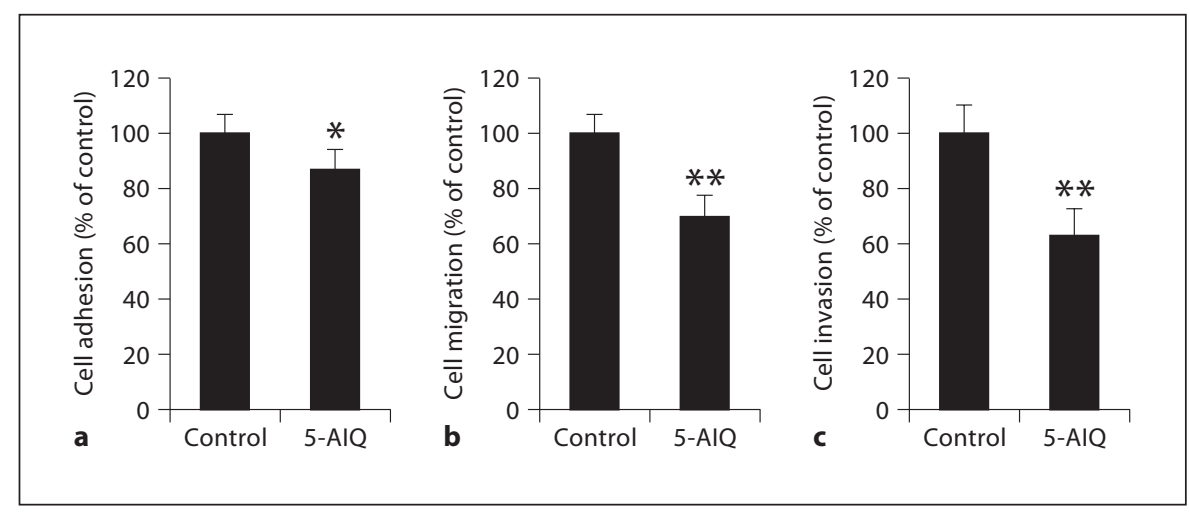

Fig. 1. PARP inhibition suppresses CT26 cell adhesion to the ECM, and their migration and invasion. Control = 5-AIQ-untreated group; 5-AIQ = 5-AIQ-treated group. a Adhesion of CT26 cells was suppressed in 5-AIQ-treated cells compared with 5AIQ-untreated (control) cells. The relative adhesion rate was calculated and normalized to the 5-AIQ-untreated (control) cells, set at $100(\mathrm{n}=5)$. $\mathbf{b}, \mathbf{c}$ In the migration and invasion assays, 5-AIQ treatment resulted in low cell penetration through the Transwell membrane compared with 5-AIQ-untreated (control) cells. Relative migration and invasion rates were calculated as the mean number of cells in five fields, and normalized to the 5-AIQ-untreated (control) cells, set at $100(\mathrm{n}=15)$. Means (columns) and $\mathrm{SD}$ (bars) of each group. ${ }^{*} \mathrm{p}<0.05,{ }^{* *} \mathrm{p}<0.01$, vs. control (Student's $t$ test).
Fig. 2. The effects of PARP inhibition on migration and invasion of CT26 cells (Transwell chamber). Staining with hematoxylin; magnification, $\times 400$. Control (a, c; 5-AIQ untreated) and 5-AIQ-treated CT26 cells $(\mathbf{b}, \mathbf{d})$ in the migration $(\mathbf{a}, \mathbf{b})$ and in the invasion assays $(\mathbf{c}, \mathbf{d})$.
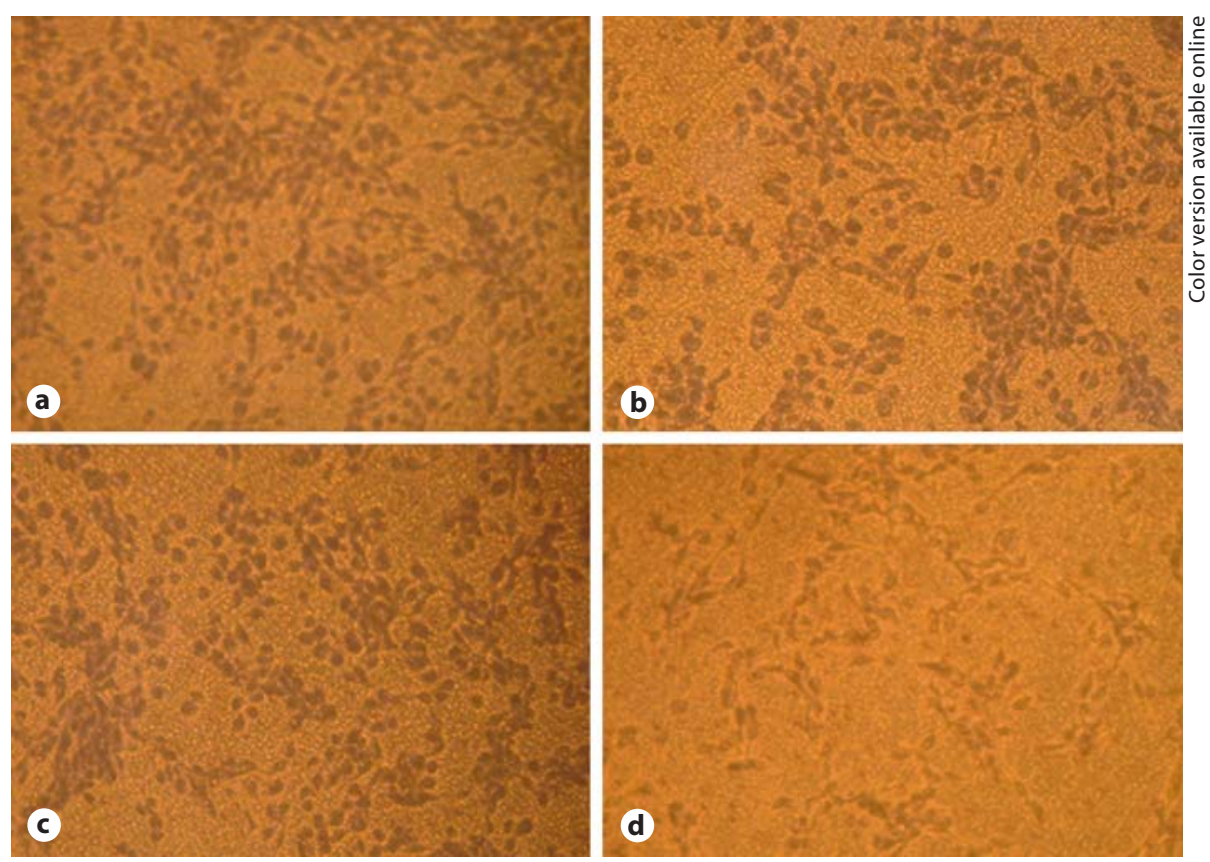

PARP inhibition contributes to a potentially anti-metastatic effect in CT26 cells.

\section{PARP Inhibition Decreases NF- $\kappa B$ Expression and}

Binding of NF- $\kappa B$ to DNA

$\mathrm{NF}-\kappa \mathrm{B}$ is an important factor in tumor metastasis, owing to its control of the expression of several metasta- sis-related genes [38]. Expression of NF- $\kappa \mathrm{B}$ was determined in CT-26 cells (pretreated with 5-AIQ and nonpretreated) by Western blot analysis, which showed a significant decrease in the amount of the NF- $\kappa \mathrm{B}$ protein in the 5-AIQ-treated cells compared to the 5-AIQ-untreated cells (fig. 3). Some decrease in the amount of PARP-1 protein was also observed (fig. 3). In parallel, the binding 

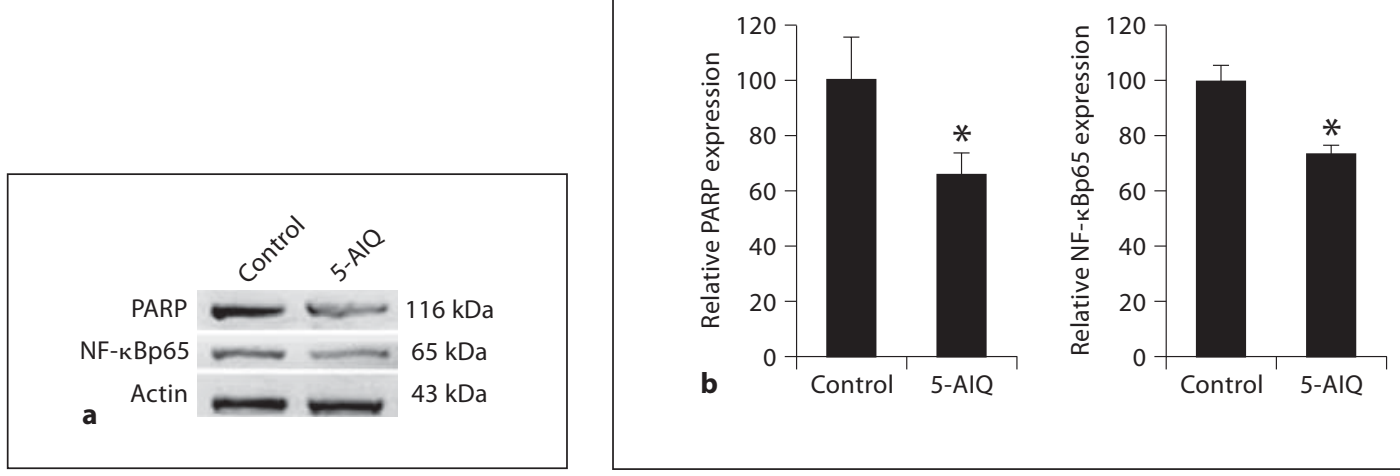

Fig. 3. PARP inhibition decreased expression of PARP and NF- $\kappa$ B by Western blot analysis. a PARP and NF$\kappa \mathrm{Bp} 65$ expression in 5-AIQ-untreated (control) and 5-AIQ-treated CT26 cells. The actin protein was used as an internal loading control. b PARP and NF- $\mathrm{kP} 65$ expression was decreased in 5-AIQ-treated cells compared with 5-AIQ-untreated (control) cells. They were calculated as the relative degradation and normalized to the 5-AIQ-untreated (control) cells, set at 100. Means (columns) and SD (bars) of each group $(\mathrm{n}=3)$ are shown. ${ }^{*} \mathrm{p}<0.05$, vs. control (Student's t test).

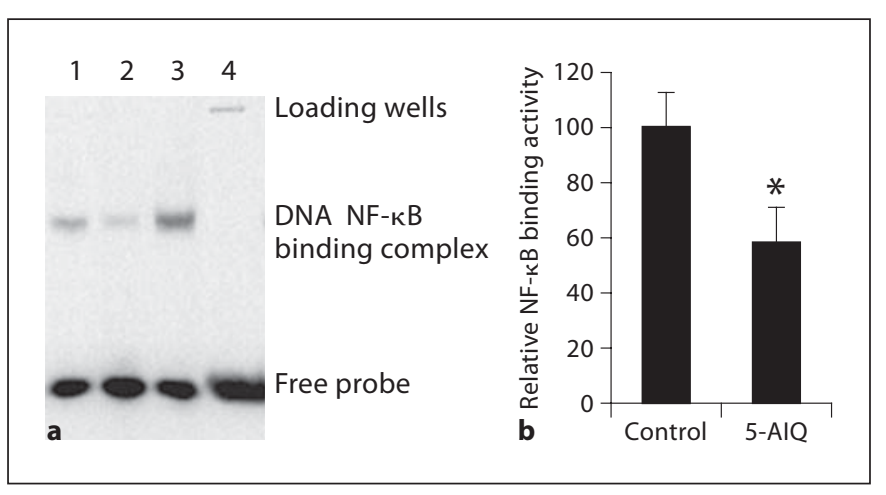

Fig. 4. PARP inhibition decreased binding of NF- $\kappa \mathrm{B}$ to DNA. a EMSA analysis was carried out for 5-AIQ-untreated (control) and 5-AIQ-treated CT26 cells. Lane $1=5$-AIQ-treated group; lane 2 = specificity control; lane $3=5$-AIQ-untreated group; lane 4 = negative control (reaction buffer only). $\mathbf{b}$ Binding of NF- $\kappa \mathrm{B}$ to DNA was decreased in 5-AIQ-treated cells compared with 5AIQ-untreated (control) cells. They were calculated as the relative degradation and normalized to the 5-AIQ-untreated (control) cells, set at 100. Means (columns) and SD (bars) of each group $(\mathrm{n}=3)$ are shown. ${ }^{*} \mathrm{p}<0.05$, vs. control (Student's t test).

of NF- $\kappa \mathrm{B}$ to DNA in 5-AIQ-treated and -untreated cells was assessed by gel shift assay. Inhibition of PARP by 5 AIQ significantly decreased the DNA-binding activity of NF- $\mathrm{B}$ (fig. 4). These results indicate that PARP inhibition can decrease the expression of NF- $\kappa \mathrm{B}$ and also the ability of NF- $\kappa \mathrm{B}$ to bind to DNA.
PARP Inhibition Down-Regulates the Expression of Metastasis-Related Genes and, Consequently, the Enzymatic Activities of MMPs

The metastatic process requires the expression of several metastasis-related genes. In particular, integrin- $\beta_{1^{-}}$ mediated cell-matrix adhesion and MMPs are critical factors for the invasion of tumor cells into surrounding tissue [39-42]. In the present work, Western blot analysis was used to measure the expression of these metastasisrelated genes and showed that the amounts of integrin $\beta_{1}$, MMP-9 and MMP-2 proteins significantly decreased by 45, 28 and 36.2\%, respectively, in 5-AIQ-treated cells compared with 5-AIQ-untreated (control) cells (fig. 5). Gelatine zymography then showed that PARP inhibition following pretreatment with 5-AIQ leads to a decrease in the proteolytic activities of MMP-2 and MMP-9 compared with CT26 cells without 5-AIQ pretreatment (fig. 6), indicating that inhibition of PARP induces suppression of expression of important metastasis-related genes.

\section{Discussion}

PARP is involved in many cellular processes, including the control of repair of damaged DNA (especially single-strand breaks) and the control of gene expression/ transcription. However, the involvement of PARP in tumor metastasis was unclear. In this study, we have shown 

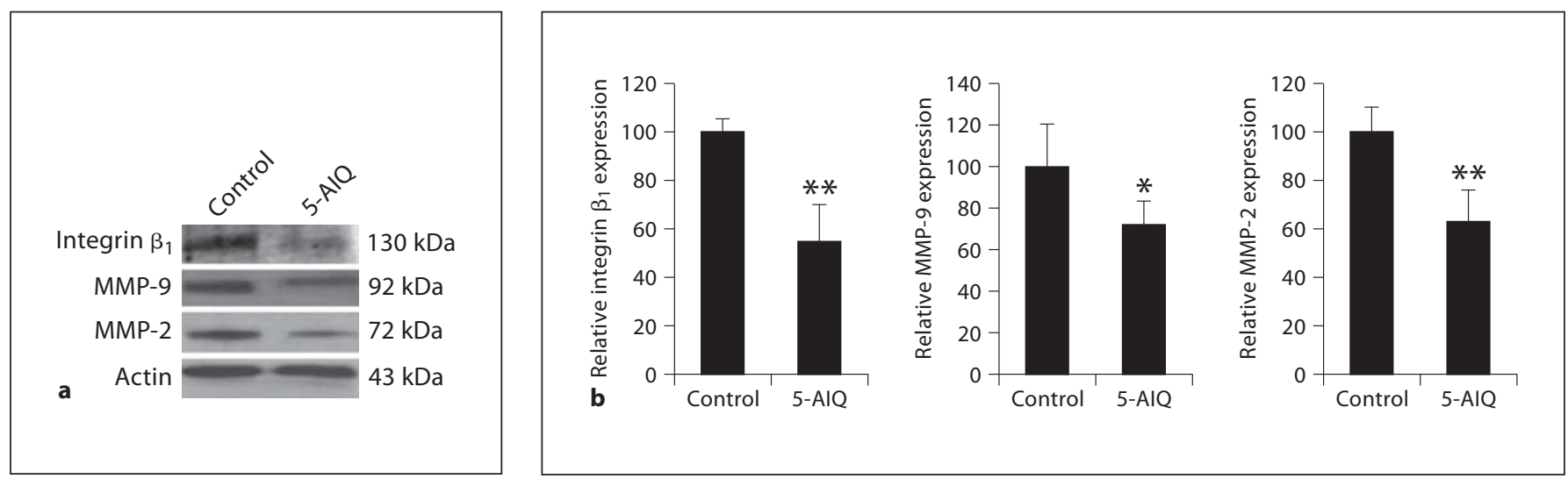

Fig. 5. PARP inhibition decreased the expression of integrin $\beta_{1}$, MMP-2 and MMP-9 (Western blot analysis). a Expression of integrin $\beta_{1}$, MMP-2 and MMP-9 in 5-AIQ-untreated (control) and 5-AIQ-treated CT26 cells. The actin protein was used as an internal loading control. b Integrin $\beta_{1}$, MMP-2 and MMP-9 expression was decreased in 5-AIQ-treated cells, vs. control. They were calculated as the relative degradation and normalized to the 5-AIQ-untreated (control) cells, set at 100. Means (columns) and SD (bars) of each group $(\mathrm{n}=6)$ are shown. ${ }^{*} \mathrm{p}<0.05,{ }^{* *} \mathrm{p}<0.01$, vs. control (Student's t test).

the following: (a) PARP inhibition by 5-AIQ decreases adhesion, migration and invasion of CT26 mouse colon adenocarcinoma cells; (b) PARP inhibition reduces expression of NF- $\mathrm{KB}$ and its DNA-binding activity; (c) PARP inhibition decreases the expression of important metastasis-related genes (integrin $\beta_{1}$, MMP-2 and MMP9) and correspondingly diminishes the proteolytic activities of these MMPs in these cells. Taken together, these results point to PARP inhibition being an effective approach to inhibition of NF- $\mathrm{\kappa B}$ activity and down-regulation of expression of its dependent genes, such as integrin $\beta_{1}$, MMP-2 and MMP-9, resulting in the inhibition of tumor metastases. Curiously, inhibition of PARP enzymatic activity also appeared to decrease the amount of PARP protein present, although the mechanism of this decrease is unclear (increased rate of degradation or diminution of expression of PARP protein possibly caused by decreased NF- $\kappa$ B activity).

Metastasis occurs by a series of steps, including degradation of basement membranes, degradation of the stromal ECM and adhesion of cells to the ECM. The integrins mediate the adhesion between tumor cells and the ECM and the MMPs degrade the ECM. Together, they are considered to be amongst the most important factors in tumor metastasis. Activation of NF- $\mathrm{KB}$ leads to up-regulation of several NF- $\kappa \mathrm{B}$-dependent genes, including integrin $\beta_{1}$ [43], MMP-2 [44] and MMP-9 [45, 46], which are key to metastases. PARP has been reported to be a co-activator of NF- $\kappa \mathrm{B}$ in many inflammatory disorders $[20$, 
activating acetylation is reversed by histone deacetylases 1-3 [50]. In the context of inflammation, pharmacological inhibition of PARP has been demonstrated to downregulate inducible nitric oxide synthase (iNOS), interleukin (IL)-1 $\beta$, IL-6 and tumor necrosis factor- $\alpha$ (TNF- $\alpha$ ) $[51,52]$ through inhibition of expression and function of NF-кB. Similarly, Zheng et al. [47] related control of expression of ICAM-1 to expression and function of NF- $\kappa \mathrm{B}$ and thus to control by PARP. Thus, the inhibition of PARP results in lower NF- $\kappa \mathrm{B}$ activity and lower expression of dependent genes. Therefore, it can be hypothesized that PARP-induced cell adhesion, migration and invasion are, at least in part, due to activation of the NF$\kappa \mathrm{B}$ pathway.

Integrins are very important to cell-matrix adhesion in the processes of tumor metastasis. Moreover, integrin $\beta_{1}$ has been reported to be one of the most critical integrin subunits in the process of adhesion of CT26 cells to fibronectin, and CT26 cells demonstrate a chemotactic response towards this matrix protein [53]. In this study, consistent with our adhesion data, we found a significant reduction in the expression of integrin $\beta_{1}$ by pharmacological inhibition of PARP. We also showed that PARP inhibition reduced expression and DNA-binding activity of NF- $\kappa \mathrm{B}$ and concomitantly diminished the expression and proteolytic activity of MMP-2 and MMP-9. In parallel, we found that inhibition of PARP inhibited the invasive capability of CT26 colon cancer cells. MMPs have been implicated in metastases because of its role in the degradation of basement membrane collagen [21, 53]. Koh et al. [19] have already shown that PARP inhibition with the relatively less potent inhibitor 3-aminobenzamide diminishes the expression of the MMP-9 protein and infiltration of neutrophils in a rat model of ischemic stroke. Similarly, Kauppinen and Swanson [49] have suggested that PARP activation is required for the neurotoxicity resulting from TNF- $\alpha$-induced release of MMP-9. In addition, Harnacke et al. [54] noted increases in the amounts of MMP-1 and MMP-9 in TUR human myeloid leukemia cells in which the PARP activity had been stimulated by 12-O-tetradecanoylphorbol-13-acetate. Here, we show that the inhibition of expression of integrin $\beta_{1}$, MMP-2 and MMP-9 resulting from inhibition of PARP by 5 -AIQ may be mediated by decreased NF- $\kappa \mathrm{B}$ activity. Based on our results, we speculate that one mechanism by which PARP induces tumor cell adhesion, migration and invasion is due to increased binding of NF- $\kappa B$ to DNA, which leads to up-regulation of NF- $\kappa \mathrm{B}$-dependent genes, including integrin $\beta_{1}$, MMP-2 and MMP-9. Thus, on the basis of our results, we propose a pathway by which PARP induces adhesion, migration and invasion of CT26 cells, partly through the NF- $\mathrm{\kappa B}$ signaling pathways.

In summary, we have presented experimental evidence which suggests that inhibition of PARP could attenuate the metastatic potential of CT26 colon carcinoma cells. We therefore propose that PARP inhibition could be an effective approach for the inactivation of NF- $\mathrm{\kappa B}$ and its dependent genes, such as integrin $\beta_{1}$, MMP-9 and MMP-2 expression, resulting in the inhibition of metastases. Further research is needed to prove this hypothesis, particularly in vivo.

\section{References}

$>1$ Woon ECY, Threadgill MD: Poly(ADPribose)polymerase inhibition - where now? Curr Med Chem 2005;12:2373-2392.

-2 Diefenbach J, Bürkle A: Introduction to poly(ADP-ribose) metabolism. Cell Mol Life Sci 2005;62:721-730.

3 Fong PC, Spicer J, Reade S, Reid A, Vidal L, Schellens JH, Tutt A, Harris PA, Kaye S, De Bono JS: Phase I pharmacokinetic (PK) and pharmacodynamic (PD) evaluation of a small molecule inhibitor of poly ADP-ribose polymerase (PARP), KU-0059436 (Ku) in patients (p) with advanced tumours. J Clin Oncol 2006;24:126S.

4 Plummer R, Lorigan P, Evans J, Steven N, Middleton M, Wilson R, Snow K, Dewji R, Calvert $\mathrm{H}$ : First and final report of a phase II study of the poly(ADP-ribose) polymerase (PARP) inhibitor, AG014699, in combination with temozolomide (TMZ) in patients with metastatic malignant melanoma (MM). J Clin Oncol 2006;24:456S.

5 Plummer R, Middleton M, Wilson R, Evans J, Jones C, Olson A, Boddy A, Curtin N, Kaufman R, Harris A, Johnston P, Newell H: Final clinical, pharmacokinetic and pharmacodynamic results of the phase I study of the novel poly(ADP-ribose)polymerase (PARP) inhibitor, AG014699, in combination with temozolomide. Clin Cancer Res 2005;11:9099S.

-6 Ratnam K, Low JA: Current development of clinical inhibitors of poly(ADP-ribose) polymerase in oncology. Clin Cancer Res 2007; 13:1383-1388.

7 Farmer H, McCabe N, Lord CJ, Tutt AN, Johnson DA, Richardson TB, Santarosa M, Dillon KJ, Hickson I, Knights C, Martin NM, Jackson SP: Targeting the DNA repair defect in BRCA mutant cells as a therapeutic strategy. Nature 2005;434:917-921.
8 Virág L, Szabó C: The therapeutic potential of poly(ADP-ribose) polymerase inhibitors. Pharmacol Rev 2002;54:375-429.

$\checkmark 9$ McDonald MC, Mota-Filipe H, Wright JA, Abdelrahman M, Threadgill MD, Thompson AS, Thiemermann C: Effects of 5-aminoisoquinolinone, a water-soluble, potent inhibitor of the activity of poly (ADP-ribose) polymerase on the organ injury and dysfunction caused by haemorrhagic shock. Br J Pharmacol 2000;130:843-850.

$>10$ Wayman N, McDonald MC, Thompson AS, Threadgill MD, Thiemermann C: 5-Aminoisoquinolinone, a water-soluble potent inhibitor of poly(adenosine $5^{\prime}$-diphosphate ribose) polymerase, reduces myocardial infarct size. Eur J Pharmacol 2001;430:93100 . 
11 Chatterjee PK, Chatterjee BE, Pedersen H, Sivarajah A, McDonald MC, Mota-Filipe H, Brown PA, Stewart KN, CuzzocreaS, Threadgill MD, Thiemermann C: 5-Aminoisoquinolinone reduces renal injury and dysfunction caused by ischemia/reperfusion. Kidney Int 2004;65:499-509.

12 Di Paola R, Genovese T, Caputi AP, Threadgill MD, Thiemermann C, Cuzzocrea S: Beneficial effects of 5-aminoisoquinolinone, a novel, potent, water-soluble, inhibitor of poly (ADP-ribose) polymerase, in a rat model of splanchnic artery occlusion and reperfusion. Eur J Pharmacol 2004;492:203-210.

13 Mota-Filipe H, Sepodes B, McDonald MC, Cuzzocrea S, Pinto R, Thiemermann C: The novel PARP inhibitor 5-aminoisoquinolinone reduces the liver injury caused by ischemia and reperfusion in the rat. Med Sci Monit 2002;8:444-453.

- 14 Cuzzocrea S, Mazzon E, Di Paola R, Genovese T, Patel NS, Muia C, Threadgill MD, De Sarro A, Thiemermann C: 5-Aminoisoquinolinone reduces colon injury by experimental colitis. Naunyn Schmiedebergs Arch Pharmacol 2004;370:464-473.

15 Genovese T, Mazzon E, Muià C, Patel NS, Threadgill MD, Bramanti P, De Sarro A, Thiemermann C, Cuzzocrea S: Inhibitors of poly(ADP-ribose)polymerase modulate signal transduction pathways and secondary damage in experimental spinal cord trauma. J Pharmacol Exp Ther 2005;312:449-457.

- 16 Cuzzocrea S, McDonald MC, Mazzon E, Dugo L, Serraino I, Threadgill MD, Caputi AP, Thiemermann C: Effects of 5-aminoisoquinolinone, a water-soluble, potent inhibitor of the activity of poly(ADP-ribose) polymerase, in a rodent model of lung injury. Biochem Pharmacol 2002;63:293-304.

17 Sanchez-Fidalgo S, Villegas I, Martin A, Sanchez-Hidalgo M, Alarcon de la Lastra C: PARP inhibition reduces acute colonic inflammation in rats. Eur J Pharmacol 2007; 563:216-223.

18 Di Paola R, Mazzon E, Muià C, Terrana D, Greco S, Britti D, Santori D, Oteri G, Cordasco G, Cuzzocrea S: 5-Aminoisoquinolin$1(2 \mathrm{H})$-one, a water-soluble poly (ADP-ribose) polymerase (PARP) inhibitor reduces the evolution of experimental periodontitis in rats. J Clin Periodontol 2007;34:95-102.

19 Koh SH, Chang DI, Kim HT, Kim J, Kim MH, Kyung SK, Bae I, Kim H, Dong WK, Seung HK: Effect of 3-aminobenzamide, PARP inhibitor, on matrix metalloproteinase-9 level in plasma and brain of ischemic stroke model. Toxicology 2005;214:131-139.

20 Hassa PO, Hottiger MO: A role of poly (ADPribose) polymerase in NF- $\mathrm{KB}$ transcriptional activation. Biol Chem 1999;380:953-959.

-21 Hassa PO, Buerki C, Lombardi C, Imhof R, Hottiger MO: Transcriptional coactivation of nuclear factor- $\mathrm{\kappa} \mathrm{B}$-dependent gene expression by p300 is regulated by poly (ADP)-ribose polymerase-1. J Biol Chem 2003;278: 45145-45153.
22 Veres B, Radnai B, Gallyas F Jr, Varbiro G, Berente Z, Osz E, Sumegi B: Regulation of kinase cascades and transcription factors by a poly(ADP-ribose) polymerase-1 inhibitor, 4-hydroxyquinazoline, in lipopolysaccharide-induced inflammation in mice. J Pharmacol Exp Ther 2004;310:247-255.

-23 Nakajima H, Nagaso H, Kakui N, Ishikawa M, Hiranuma T, Hoshiko S: Critical role of the automodification of poly(ADP-ribose) polymerase-1 in nuclear factor- $\kappa \mathrm{B}$-dependent gene expression in primary cultured mouse glial cells. J Biol Chem 2004;279: 42774-42786.

24 Tentori L, Leonetti C, Scarsella M, Muzi A, Mazzon E, Vergati M, Forini O, Lapidus R, Xu W, Dorio AS, Zhang J, Cuzzocrea S: Inhibition of poly(ADP-ribose) polymerase prevents irinotecan-induced intestinal damage and enhances irinotecan/temozolomide efficacy against colon carcinoma. FASEB J 2006;20:1709-1711.

25 Kang YH, Yi MJ, Kim MJ, Park MT, Bae S, Kang CM, Cho CK, Park IC, Park MJ, Rhee $\mathrm{CH}$, Hong SI, Chung HY: Caspase-independent cell death by arsenic trioxide in human cervical cancer cells: reactive oxygen species-mediated poly(ADP-ribose) polymerase-1 activation signals apoptosis-inducing factor release from mitochondria. Cancer Res 2004;64:8960-8967.

-26 Trofimova I, Dimtchev A, Jung M, Rosenthal D, Smulson M, Dritschilo A, Soldatenkov V: Gene therapy for prostate cancer by targeting poly(ADP-ribose) polymerase. Cancer Res 2002;62:6879-6883.

27 Martin-Oliva D, Aguilar-Quesada R, O’Valle F, Muñoz-Gámez JA, Martínez-Romero R, García del Moral R, Ruiz de Almodóvar JM, Villuendas R, Piris MA, Oliver FJ: Inhibition of poly(ADP-ribose) polymerase modulates tumor-related gene expression, including hypoxia-inducible factor-1 activation, during skin carcinogenesis. Cancer Res 2006;66 5744-5756.

28 Rajesh M, Mukhopadhyay P, Godlewski G, Bátkai S, Haskó G, Liaudet L, Pacher P: Poly(ADP-ribose)polymerase inhibition decreases angiogenesis. Biochem Biophys Res Commun 2006;350:1056-1062.

29 Hao LX, Wang YL, Cai L, Li YY: Inhibitory effect of 5-aminoisoquinolinone on PARP activity in colon carcinoma cell line HT29. Ai Zheng 2007;26:566-571.

30 Watson CY, Whish WJD, Threadgill MD: Synthesis of 3-substituted benzamides and 5 -substituted isoquinolin-1(2H)-ones and preliminary evaluation as inhibitors of poly(ADP-ribose)polymerase (PARP). Bioorg Med Chem 1998;6:721-734.

- 31 Szabó G, Bährle S, Stumpf N, Sonnenberg K, Szabó É, Pacher P, Csont T, Schulz R, Dengler TJ, Liaudet L, Jagtap PG, Southan GJ: Poly(ADP-ribose) polymerase inhibition reduces reperfusion injury after heart transplantation. Circ Res 2002;90:100-106.
32 von Lampe B, Stallmach A, Riecken EO: Altered glycosylation of integrin adhesion molecules in colorectal cancer cells and decreased adhesion to the extracellular matrix. Gut 1993;34:829-836.

- 33 Zeng ZS, Cohen AM, Guillem JG: Loss of basement membrane type IV collagen is associated with increased expression of metalloproteinases 2 and 9 (MMP-2 and MMP-9) during human colorectal tumorigenesis. Carcinogenesis 1999;20:749-755.

34 Odero-Marah VA, Khalkhali-Ellis Z, Chunthapong J, Amir S, Seftor RE, Seftor EA, Hendrix MJ: Maspin regulates different signaling pathways for motility and adhesion in aggressive breast cancer cells. Cancer Biol Ther 2003;2:398-403.

- 35 Wick W, Wagner S, Kerkau S, Dichgans J, Tonn JC, Weller M: BCL-2 promotes migration and invasiveness of human glioma cells. FEBS Lett 1998;440:419-424.

-36 Lee HK, Lee JH, Kim M, Kariya Y, Miyazaki $\mathrm{K}$, Kim EK: Insulin-like growth factor-1 induces migration and expression of laminin-5 in cultured human corneal epithelial cells. Invest Ophthalmol Vis Sci 2006;47:873882.

37 Quesada A, Barbacid M, Mira E, FernádezResa P, Máquez G, Aracil M: Evaluation of fluorometric and zymographic methods as activity assays for stromelysins and gelatinases. Clin Exp Metastasis 1997;15:26-32.

38 Lee CH, Jeon YT, Kim SH, Song YS: NF-кB as a potential molecular target for cancer therapy. Biofactors 2007;29:19-35.

-39 Felding-Habermann B: Integrin adhesion receptors in tumor metastasis. Clin Exp Metastasis 2003;20:203-213.

40 Deryugina EI, Quigley JP: Matrix metalloproteinases and tumor metastasis. Cancer Metastasis Rev 2006;25:9-34.

41 Curran S, Murray GI: Matrix metalloproteinases: molecular aspects of their roles in tumour invasion and metastasis. Eur J Cancer 2000;36:1621-1630.

42 Nagakawa Y, Aoki T, Tsuchida A, Koyanagi Y: Histologic features of venous invasion, expression of vascular endothelial growth factor and matrix metalloproteinase- 2 and matrix metalloproteinase-9, and the relation with liver metastasis in pancreatic cancer. Pancreas 2002;24:169-178.

-43 Wang J, Manning B, Wu Q, Blankson S, Bouchier-Hayes D, Redmond HP: Endotoxin/lipopolysaccharide activates NF- $\mathrm{B}$ and enhances tumor cell adhesion and invasion through a $\beta_{1}$ integrin-dependent mechanism. J Immunol 2003;170:795-804.

-44 Marin-Castaño ME, Elliot SJ, Potier M, Karl M, Striker LJ, Striker GE, Csaky KG, Cousins SW: Regulation of estrogen receptors and MMP-2 expression by estrogens in human retinal pigment epithelium. Invest Ophthalmol Vis Sci 2003;44:50-59. 
45 Hozumi A, Nishimura Y, Nishiuma T, Kotani Y, Yokoyama M: Induction of MMP-9 in normal human bronchial epithelial cells by TNF- $\alpha$ via NF- $\kappa$ B-mediated pathway. Am J Physiol Lung Cell Mol Physiol 2001;281: L1444-L1452.

46 Cheng JC-H, Chou CH, Kuo ML, Hsieh CY: Radiation-enhanced hepatocellular carcinoma cell invasion with MMP-9 expression through PI3K/Akt/NF- $\mathrm{B}$ signal transduction pathway. Oncogene 2006;25:70097018.

47 Zheng L, Szabó C, Kern TS: Poly(ADP-ribose) polymerase is involved in the development of diabetic retinopathy via regulation of nuclear factor- $\kappa$ B diabetes 2004;53:2960 2967.
48 Pétrilli V, Herceg Z, Hassa PO, Patel NS, Di Paola R, Cortes U, Dugo L, Filipe HM, Thiemermann C, Hottiger MO, Cuzzocrea S, Wang ZQ: Noncleavable poly(ADP-ribose) polymerase-1 regulates the inflammation response in mice. J Clin Invest 2004;114: 1072-1081.

49 Kauppinen TM, Swanson RA: Poly(ADP-ribose) polymerase-1 promotes microglial activation, proliferation, and matrix metalloproteinase-9-mediated neuron death. J Immunol 2005;174:2288-2296.

50 Hassa PO, Haenni SS, Buerki C, Meier NI, Lane WS, Owen H, Gersbach M, Imhof R, Hottiger MO: Acetylation of poly(ADP-ribose) polymerase-1 by p300/CREB-binding protein regulates coactivation of $\mathrm{NF}-\kappa \mathrm{B}-\mathrm{de}$ pendent transcription. J Biol Chem 2005; 280:40450-40464.

-51 Hauschildt S, Scheipers P, Bessler W, Schwarz K, Ullmer A, Flad HD, Heine H: Role of ADP-ribosylation in activated monocytes/ macrophages. Adv Exp Med Biol 1997;419: 249-252.
2 Genovese T, Mazzon E, Di Paola R, Muià C, Threadgill MD, Caputi AP, Thiemermann C, Cuzzocrea S: Inhibitors of poly(ADP-ribose) polymerase modulate signal transduction pathways and the development of bleomycin-induced lung injury. J Pharmacol Exp Ther 2005;313:529-538.

53 Geng L, Ali SA, Marshall JF, Mackay CL, Hart IR, Delcommence M, Streuli CH, Rees $\mathrm{RC}$ : Fibronectin is chemotactic for CT $26 \mathrm{co-}$ lon carcinoma cells: sub-lines selected for increased chemotaxis to fibronectin display decreased tumorigenicity and lung colonization. Clin Exp Metastasis 1998;16:683-691.

54 Harnacke K, Kruhøffer M, Ørntoft TF, Hass R: Down-modulation of poly(ADP-ribose) polymerase-1 (PARP-1) in human TUR leukemia cells restores transcriptional responsiveness for differentiation and cell cycle arrest. Eur J Cell Biol 2005;84:885-896. 